\title{
Anabases
}

ANABASES Traditions et réceptions de l'Antiquité

12 | 2010

Varia

\section{Parabalani : A Terrorist Charity in Late Antiquity}

\section{Glen W. Bowersock}

\section{OpenEdition}

\section{Journals}

Electronic version

URL: http://journals.openedition.org/anabases/1061

DOI: 10.4000/anabases.1061

ISSN: 2256-9421

\section{Publisher}

E.R.A.S.M.E.

\section{Printed version}

Date of publication: 1 October 2010

Number of pages: 45-54

ISSN: 1774-4296

\section{Electronic reference}

Glen W. Bowersock, «Parabalani : A Terrorist Charity in Late Antiquity », Anabases [Online], 12 | 2010, Online since 01 October 2013, connection on 20 October 2019. URL : http://journals.openedition.org/ anabases/1061 ; DOI : 10.4000/anabases.1061 


\section{Parabalani:}

\section{A Terrorist Charity in Late Antiquity ${ }^{1}$}

G. W. BOWERSOCK

$\mathrm{I}_{\mathrm{N}}$ THE YEAR 415 a mob of Christian terrorists swarmed through the streets of Alexandria in Egypt. They were apparently agents of the city's bishop, the Patriarch Cyril, who had become embroiled in a bitter dispute with the secular magistrate, Orestes, serving as prefect under the authority of the emperor at Constantinople. A leading mathematician and neoplatonic philosopher, the glamorous Hypatia, appeared to have taken sides with Orestes against Cyril, and her charismatic role among Alexandria's pagans made her opposition potentially threatening to the church. Or so it seemed. The mob unleashed by Cyril wrenched Hypatia out of a chariot in which she was riding, stripped and disfigured her, dismembered her body, and took the shattered remains to be burned $^{2}$.

This horrifying episode of ecclesiastical intimidation seems to lie behind a ruling from the emperors of the Byzantine empire in the very next year ${ }^{3}$. It looks as if the miscreants who destroyed Hypatia all came from the ranks of city's poor, and all owed their service under the patriarch to enrollment in a charitable organization dedicated to helping the needy and the sick. The members of this organization appear to be the persons to whom the emperors direct their attention in 416. These people illustrate arrestingly how charitable good works could lead not only to an abuse of ecclesiastical

1 I am very happy to offer this paper in honor of my friend Leandro Polverini, with whom I have long shared many scholarly interests.

2 M. DzIELSKA, Hypatia of Alexandria, Cambridge MA, 1995, p. 83-100 ("The Circumstances of Hypatia's Death").

3 Cod. Theod. 16. 2. 42 (29 Sept. 416). This document will be discussed below. 
power but to a continuing threat of terrorism in early Byzantine cities for a century or more. Rarely has the relation between power and philanthropy been so clearly exposed.

Let us survey briefly the evolution of philanthropic care for the needy in antiquity. It is a curious fact, rarely observed, that for most of antiquity the Greeks and the Romans had tended to keep their poor and their sick in separate categories. Although in late antiquity the hospital ultimately united the interrelated demands of poverty and sickness as no institution had before, this conjunction was late in coming ${ }^{4}$. Throughout much of Graeco-Roman antiquity the impoverished were left to beg or rely on private or governmental doles. The rapidly developing science of medicine was devoted to the diagnosis and cure of individual sufferers. Public physicians were available for the sick much as public scribes were available for the illiterate. But in a polytheist world the teaching and practice of medicine was regularly associated with healing gods, Asclepius above all. The great shrines of Asclepius at Pergamum and Kos were centers of medical study and practice, and their success only encouraged fraudulent clones such as the popular cult of the healing snake god, Glycon, in northern Asia Minor. The great doctors, such as Galen, could enjoy a prestige comparable to that of leading intellectuals in philosophy and rhetoric. But none of these practitioners was associated with anything resembling institutionalized care for the needy until the advent of Christianity.

The link with Christianity in the early Byzantine age is generally acknowledged in the scholarly literature. Timothy Miller, in his study of Byzantine hospitals, wrote unequivocally, "Christianity created the hospitals of the Byzantine Empire". Peter Brown observed in his Stern Lectures in Jerusalem, "What needs to be stressed is that the Christian poorhouse-cum-hospital was a novel institution in the ancient world ${ }^{6 "}$. And in their recent survey of medicine and society in antiquity Isabella Andorlini and Arnaldo Marcone declare emphatically, "Tra le grandi innovazioni in campo medico che si devono all'età bizantina c'è senz'altro la creazione dei primi ospedali ${ }^{7 ”}$.

But the Christian initiative at its beginning in the fourth century was dedicated more to supporting the poor and the homeless than to treating the ill. The indigent were naturally often sick, but it was their poverty, not their health, that first inspired Christian charity. Peter Brown's phrase "poorhouse-cum-hospital" catches this point perfectly. It is true that for the post-Constantinian church the needy often included lepers, but this was less because they were ill than because they were social outcasts

4 Cf. T. S. Miller, The Birth of the Hospital in the Byzantine Empire, Baltimore, 1985.

5 Miller, op. cit., p. 50.

6 P. Brown, Poverty and Leadership in the Later Roman Empire, Hanover NH, 2002, p. 34 .

7 I. Andorlini - A. Marcone, Medicina, Medico, e Società nel Mondo Antico, Florence, 2004, p. 95. 
and consequently relegated to a class comparable to the indigent. They needed to be taken off the streets. The names for the early hostels that offered accommodation

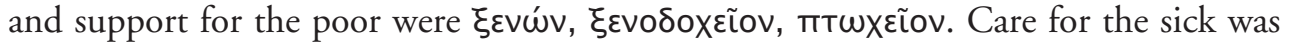
clearly an ancillary service, and naturally in such places it was only available for the

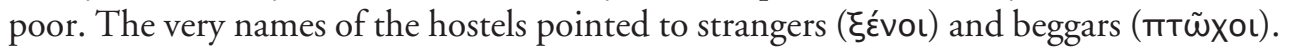
They served to emphasize the primacy of poverty in the church's mission. The emergence of a word for hospital, vобокоцг̃ov, came only after the first phase of Christian philanthropy.

The earliest accounts amply document poverty as the church's primary concern and sickness as ancillary ${ }^{8}$. In the writings of the Cappadocian fathers as well as in the emperor Julian's efforts to adapt such care for his pagan church it is always poverty that dominates the discussion. For example, one of the first poorhouses in late antiquity was the Basileias near Cappadocian Caesarea that owed its foundation to Saint

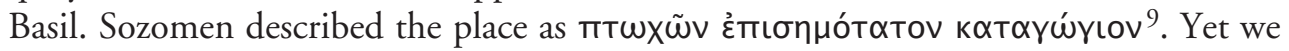
know from Gregory of Nazianzus that this "storehouse of piety" welcomed lepers as well as beggars since they were shunned by the populace ${ }^{10}$. Basil brought together, as Gregory's biographer says, all indigent and enfeebled people, and he called the resi-

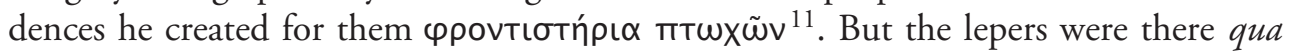
beggars, because they were poor and homeless.

At another of the early foundations in the Byzantine empire, Eustathius' птшхотрофкіоv in Armenian Sebasteia, the situation, like the name, was similar. Epiphanius reports that among the beggars welcomed into Eustathius' hostel were lepers along with others who were unable to look after themselves ${ }^{12}$. When Julian, drawing upon his youthful experience as a Christian, advocated to his pagan clergy the institution of philanthropy, he particularly urged that the wealthy dedicate money to

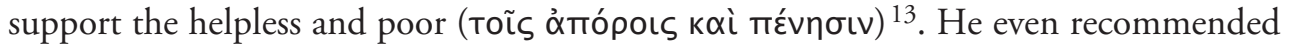
helping those in prison, whether before trial or after it, and he instructed Arsacius, the

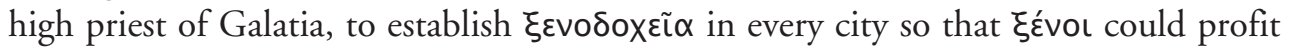
from his philanthropy. But he says nothing at all about caring for the sick.

8 An invaluable repertorium of institutions to help the poor and sick may be found in $\mathrm{K}$.

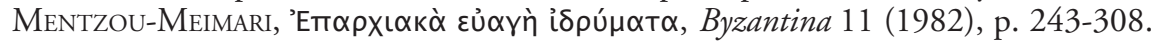

9 Sozomenus, Hist. Eccles. 6, 34, 9.

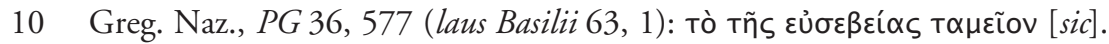

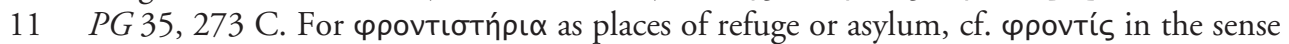
of "caring for": A. KuRmann, Gregor von Nazianz Oratio 4 gegen Julian: Ein Kommentar, Schweizerische Beiträge zur Altertumswissenschaft, Heft 19, Basel, 1988, p. 376.

12 Epiphanius, Panarion 3, 333, 1 (Holl).

13 Jul., Epist. 84. Cf. Greg. Naz., Orat. 4, 111, with the commentary of A. Kurmann, op. cit. (n. 11), p. 374-377. 
A famine in Edessa, the Mesopotamian home of the Syriac poet and saint Ephrem, wrought havoc in that city shortly before Ephrem died in 373. This led him to establish what may well have been the first refuge specifically for the care and support of the sick. He set up three hundred beds in public premises with money he raised from the rich ${ }^{14}$. Half a century was to pass before anything comparable appeared again, and when it did it was once more in Edessa, in the episcopate of Rabbula ${ }^{15}$.

The problematic character of Christian philanthropy in this early period is nowhere so vividly illustrated, in all its complex motivation, as in the documentation for a still controversial corps of social workers. They are mentioned twice in the Theodosian Code and twice in reaffirmations of the Theodosian rulings in the Justinianic Code. They are customarily called parabalani, but the spelling and sense of their name are both in question, as well as their precise responsibilities and the extent of their diffusion in the Mediterranean world. An examination of these people, who have been called at various times "gamblers", "bath attendants", "nurses", and "rednecks", opens up a conjunction of power, poverty, and sickness at the intersection of secular and ecclesiastical authority. In looking at the parabalani we are putting early Christian philanthropy under a microscope. These were, almost certainly, the murderers of Hypatia.

The fundamental documents for the parabalani are two imperial decrees that Theodosius and Honorius issued to the eastern praefectus praetorio in 416 and $418^{16}$. A century later Justinian reaffirmed the Theodosian orders in virtually the same language ${ }^{17}$, and the repetition of these texts in the Code of Justinian serves to demonstrate that the problem they addressed had not gone away. Let us turn now to the details of that problem.

14 Sozomenus, Hist. Eccles. 3, 16, 15.

15 Vita Rabbulae, p. 202-203 of OverbeCK's original Syriac edition (1865), p. 94 of the Chrestomathie in BrocKelmanN's Syrische Grammatik, and now, conveniently, in the first English translation ever published: R. Doran, Stewards of the Poor. The Man of God, Rabbula, and Hiba in Fifth-Century Edessa, Kalamazoo, 2006, p. 100-101. Rabbula also set up a separate hospital for women.

16 Cod. Theod. 16, 2, 42 (29 Sept. 416): ... quod quidem terrore eorum, qui parabalani nuncupantur, legationi insertum est, placet nostrae clementiae, ut nihil commune clerici cum publicis actibus vel ad curiam pertinentibus habeant. Praeterea eos, qui parabalani vocantur non plus quam quingentos esse praecipimus, ita ut non divites et qui hunc locum redimant, sed pauperes a corporatis pro rata Alexandrini populi praebeantur... Quibus neque ad quodlibet publicum spectaculum neque ad curiae locum neque ad iudicium adcedendi licentiam permittimus, nisi forte singuli ob causas proprias et necessitates iudicem adierint... Cf. Cod. Theod. 16, 2, 43 (3 Feb. 418): ... parabalani, qui ad curanda debilium aegra corpora deputantur... exceptis honoratis et curialibus.

17 The text of Justinian, cited in Cod. Theod. Mommsen-Kreuger provides a deviant form parabolanin. 
A delegation from Egyptian Alexandria had gone to Constantinople with a number of obviously petty complaints (inutilia), but on one matter the emperors chose to make a ruling. In view of an unspecified terror caused by those called parabalani they declared that clerics were to have nothing to do with public acts or matters pertaining to the curia: ... quod quidem terrore eorum, qui parabalani nuncupantur, legationi insertum est, placet nostrae clementiae, ut nibil commune clerici cum publicis actibus vel ad curiam pertinentibus habeant. As earlier scholars have recognized, this meant that the offending parabalani were themselves a group of minor clerici, and therefore subject to the authority of the bishop (or patriarch) of Alexandria, who is explicitly mentioned in the lacunose opening of the first document. With the first document appearing in 416 the connection with Hypatia seems inevitable. The word terror in this context is strong language.

The emperors ordered that the parabalani be limited to a corpus of no more than five hundred persons and that they be nominated by the corporati from the ranks of the city's poor [pauperes] in a way that would reflect their distribution among the people of Alexandria [pro rata Alexandrini populi]. Presumably this clause was designed to prevent unbalanced representation from different parts of the city. No persons of means [divites] or persons who could afford to buy the job [qui hunc locum redimant] were eligible. Nominations were to be forwarded to the local praefectus Augustalis, and he in turn would refer them to the praefectus praetorio. The emperors then spelled out an overall prohibition on the presence of parabalani at the theatre, at the curia, and in court (except on those occasions when one of them might be on trial or be bringing an action).

It is only in the second document, from two years later, that Theodosius and Honorius described the work of this unusual corpus of people - people who had, by law, to be poor, who had sown terror in their city, and who were forbidden access to three of the most important institutions in any Greek city. In raising the allowed number from five hundred to six hundred, the emperors wrote of parabalani, qui ad curanda debilium aegra corpora deputantur. Clearly the services of these people were sufficiently in demand that an extra hundred persons had to be authorized. The second document emphasizes once again and unmistakably that they must be poor: exceptis honoratis et curialibus.

From any historical perspective these texts reveal an astonishing social arrangement. Six hundred persons, who must all be poor and representative of the entire city's indigent population, occupy themselves, under the supervision of the patriarch, with the care of "the sick bodies of the weak". A history of their causing terror not long before suggests that these indigent recruits could be rowdy and obstreperous, and that is undoubtedly why they are not allowed to go to the theatre, the curia, and the courts. These are all places where tumult could arise.

Stepping back for a moment to assess the picture that emerges thus far, we have found the Alexandrian patriarch to be in charge of a substantial group charged with attending to the sick in some way [ad curanda debilium aegra corpora]. It is not clear 


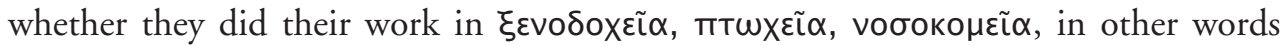
in a hospital setting, or whether they worked with the ailing in the streets. What is extraordinary here is that they themselves had to be poor, but obviously in good health. Their capacity to cause terror would imply physical strength as well as health, and so it is not unreasonable to believe that their real job was to remove the ailing from the city streets into places of isolation. This consideration points to sick people of all kinds, including lepers, whom we have already seen were transferred to the first hostels of the Christian church in the fourth century. Alexandre Philipsborn acutely perceived in 1950 that the parabalani were very probably a brigade of ambulanciers - ambulance personnel or paramedics ${ }^{18}$.

Hence it seems that the church in Alexandria managed to remove the sick and diseased from the city streets through the recruitment of healthy poor persons, who were beholden to the bishop. They could therefore become his personal militia, and it appears likely that their terror in 415 or so was carried out at his behest - certainly if the troubles did indeed arise in connection with the murder of Hypatia. This means that the cause of Christian charity and philanthropy was effectively used to promote the political power of the patriarch in Alexandria. But, by confining the corpus of parabalani to the poor and sequestering them from places of potential civic disturbance, Theodosius and Honorius minimized the force of this instrument of episcopal power. They prohibited an alliance between the rich and the clergy, while at the same time promoting the useful employment of the poor across the entire city.

Such, at least, is the image of the parabalani that emerges from the legislation in the Theodosian Code. It stipulates deployment of the healthy poor in the service of the sick, and, in all probability, in the removal of lepers and other diseased or sick persons to Christian hostels. We have no reason at all to imagine that these minor clerics were doctors who went about providing house calls, nor is there any indication that they were assigned to work inside any of the local hostels. Their rowdiness would hardly

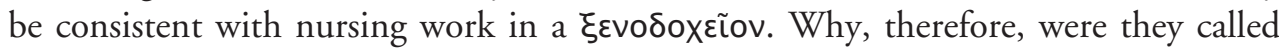
parabalani - or were they?

Henri Grégoire noticed in the Acts of the Council of Chalcedon in 451 a reference to a disturbance at the "Robber" Council of Ephesus two years earlier ${ }^{19}$. Some monks with Barsaumas had stormed a church, and among their number were unruly persons described as $\pi \alpha \rho \alpha \beta \alpha \lambda \alpha v \varepsilon \tilde{c} \varsigma$, bath-attendants. The word is preternaturally rare, but is found on one papyrus and is prima facie plausible. Grégoire proclaimed, perhaps a little too triumphantly, that here was the real explanation of the name of the para-

18 A. Philipsborn, "La compagnie d'ambulanciers 'parabalani' d'Alexandrie", Byzantion 20 (1950), p. 185-190.

19 H. GréGoire, "Sur le Personnel hospitalier des églises", Byzantion 13 (1938), p. 283-285. Cf. $\pi \alpha \rho \alpha \beta \alpha \lambda \alpha v \varepsilon \tilde{\varsigma}$ (P. Iand. 154). Acta Conc. Oec (ed. Schwartz), vol. 2, I,1, p. 179:

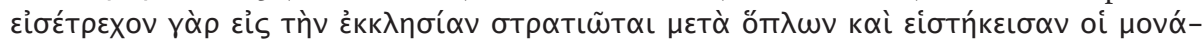

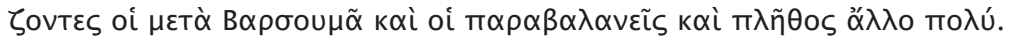


balani. They were bath-attendants, who picked up the sick on the side. This makes no sense at all, despite a predilection to accept Grégoire's idea. (Philipsborn, publishing in Grégoire's own journal, Byzantion, said that the etymology of the word parabalani a été découverte par M.H. Grégoire.) It is by no means obvious why bath-attendants would be ambulanciers or why Theodosius should set up such an elaborate procedure for the selection and conduct of such bath-attendants. Furthermore, the citizens of Alexandria would not have been pleased to find their great public baths a place for people suffering from diseases, including leprosy.

The textual transmission of both the Theodosian and Justinianic codes shows considerable uncertainty about the spelling of the name of those poor clerics who attended to the debilium aegra corpora. The text of Justinian introduces the letter $\mathrm{O}$ in place of the third A in parabalanus, and it is worth looking more profoundly into the possibility that parabolanus is in fact correct.

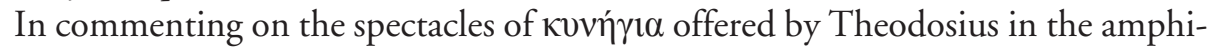
theatre of Constantinople, the ecclesiastical historian Socrates includes a pertinent anecdote that has, strangely, never been examined in the many treatments of the etymology of parabalanus/parabolanus. The people shouted to have one of the well-built parabolo $i$

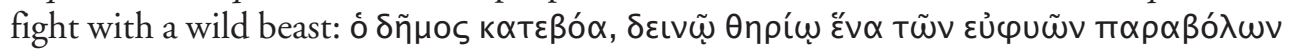

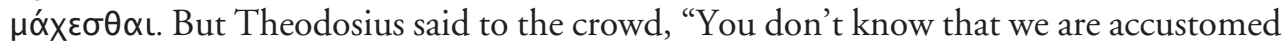

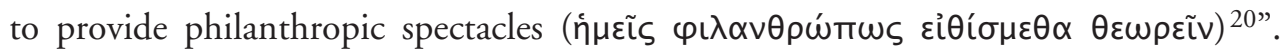
And the crowd learned from this, we are told, to look at spectacles philanthropically ( $\varphi \iota \lambda \alpha \vee \theta \rho \omega ́ \pi \omega \varsigma \theta \varepsilon \tilde{\alpha} \sigma \theta \alpha \iota)$. Socrates seems to be distinguishing the use of $\theta \varepsilon \omega \rho i ́ \alpha$ (and its related verb) in the sense of a public entertainment or spectacle, and the passive act of watching as expressed by the verb $\theta \varepsilon \tilde{\alpha} \sigma \theta \alpha \mathrm{L}$.

The strapping men are called paraboloi, from an adjective that means "taking risks", from $\pi \alpha \rho \alpha \beta \alpha ́ \lambda \lambda \omega$, "to stake, expose to risk". Jeanne and Louis Robert have

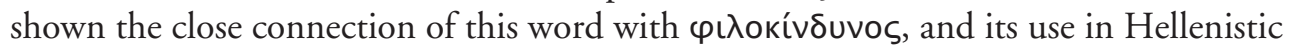
and Roman Greek ${ }^{21}$. The appearance of these vigorous men at Constantinople under Theodosius provides a much more persuasive parallel with the persons in the decrees of 416 and 418 than do the bath-attendants at the Council of Ephesus. In fact, the emperor's response to the crowd suggests that the role of these paraboloi in the city was philanthropic: "We are accustomed to provide philanthropic spectacles." It is easy to imagine that the sight of these men picking up lepers and transporting them to hostels was what Theodosius meant. And, by saying this, he taught the people in the amphitheatre to "look" philanthropically.

The Christian use of the word parabolos as a term for taking risks in the service of Christ can be traced back at least as far as Eusebius in his Theophany, a work that can be dated about 325. Although the relevant passage exists today only in Syriac it has

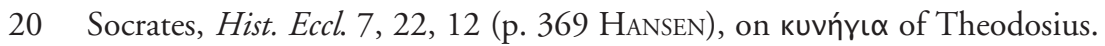

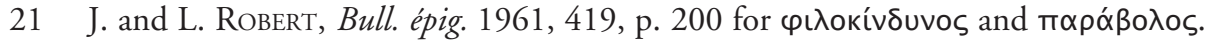


been clear from the first publication of the manuscript in 1842 that the Syriac word Rie مian represents a transliteration from Eusebius' Greek, although not necessarily from parabolarios, as proposed by the first translator and taken up in the standard Syriac Thesaurus ${ }^{22}$. (Such a form is not attested in Greek, although parabolarius does appear in the Latin of Firmicus Maternus ${ }^{23}$.) In any case, the element, parabol, transliterated from Greek, is beyond doubt. Eusebius is writing here about the courage of Christians in the face of opposition, and he suggests that one might imagine they were motivated by a desire for profit or sex: "Perhaps", he wrote, "we would be likely to think that they addressed the matter because of these things and were paraboloi up to the point of death." But, he goes on, they preached against such vices. There is, of course, no suggestion in Eusebius that the word had at this early date been appropriated to designate a cadre of minor clerics to perform social work among the poor and the sick, but that could naturally have followed later as a badge for a confraternity of risk-taking Christians.

In fact both the word and the group it came to designate bear a close resemblance to the better known philoponoi in Alexandria. These too cared for the poor and the sick, and although they appear to have constituted a lay association rather than a clerical one they had close connections with local churches and monasteries. Zacharias, author of the Life of Severus, joined the Alexandrian philoponoi and described their work and character ${ }^{24}$. In the Syriac text of the Life, which is the only text of the work we have, these people are said to devote themselves to the care of "the needy 25 ". They took their name from their character, "lovers of toil", just as the parabolani were risk-takers. A precious text of Sophronius reveals that, again like the parabolani, the philoponoi were themselves indigent citizens who dedicated their lives to helping others:

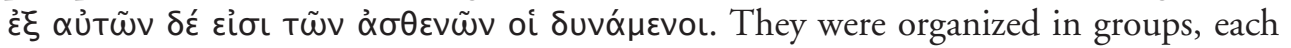
with its own $\varphi$ iภomóviov, a kind of club-house connected with a monastery where the philoponoi would meet and possibly offer medical services ${ }^{26}$. Zacharias reveals that

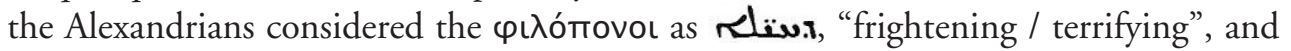
therefore in this respect as well they bore a resemblance to the parabalani.

Zacharias provides additional information about groups of tough lower-class

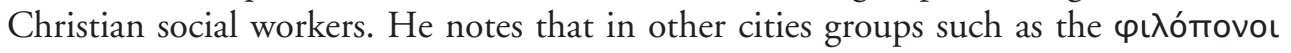

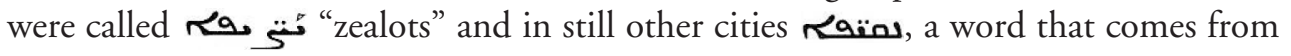

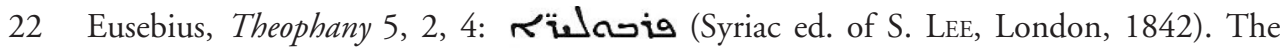
word is lost in GRESSMANN's German translation in the GCS edition (rev. LAMINSKI, p. 235): dann wäre es vielleicht wahrscheinlich von ihnen zu meinen, daß sie deswegen die Sache machten und bis zum Tode Wagehälse waren.

23 Firm. Matern., Math. 8, 10, 4: venatores arenarii parabolarii.

24 Zacharias, Life of Severus: snal.a ( $\varphi$ ìómovo PO 2 [Kugener, p. 12 and 24]).

25 Zacharias, PO 2 p. 12.

26 Sophronius, Narratio mirac. SS Cyri et Joannis 6. 


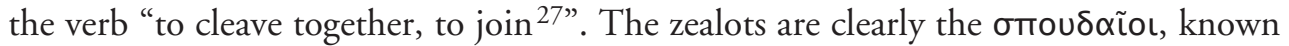
as a confraternity from late antique texts and long seen as a parallel group to the $\varphi\left(\lambda\right.$ ó$^{-}$

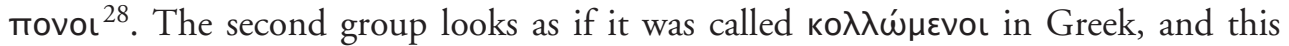
would indeed be a plausible term for such a confraternity. The name would evoke St. Paul's use of this verb to advocate "cleaving unto the good" (Romans 12. 9 ко $\lambda \lambda \omega ́ \mu \varepsilon-$

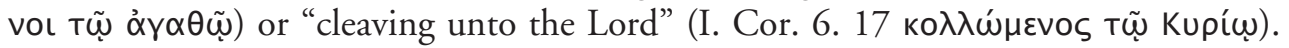
The Greek word, which could also mean sexual intercourse, as I Cor. 6. 16 shows Paul knew well, is exactly parallel in this respect with the Syriac verb הan. Ewa Wipszycka, who catalogued the confraternities of late antiquity, only knew Kugener's translation of the noun as compagnons and said she knew of no examples ${ }^{29}$. What we need to look for now is ко $\lambda \lambda \omega ́ \mu \varepsilon v o l$ as a confraternity. Although this name does not yet seem to be attested, it is really the only Greek word that Zacharias could be rendering here.

Zacharias' explicit references to groups in other cities, together with Socrates' example of the scene in Constantinople and the invasion of churches mentioned in the conciliar acts, prove that disruptive groups of the poor, organized to provide care for lepers and the sick generally, were not confined to Alexandria. The designation of these people as bath-attendants in the conciliar record must not be considered, as Grégoire supposed, the correct name and occupation of these people but rather as a corruption of the name parabolani. The word had already suffered the slight orthographic change to parabalani, which could even have become standard by the time of Theodosius. The appearance of $\pi \alpha \rho \alpha \beta \alpha \lambda \alpha v \varepsilon \tilde{s}$ in a papyrus (P. Iand. 154) proves nothing more than that this was indeed the word for bath-attendants. In a list for distribution of wine they are listed immediately after lecticarii, and no one has yet imagined that lecticarii were committed to care of the indigent.

From the ranks of the poor, therefore, came some powerful groups of strong and healthy persons in the service of the church, either as minor clerics or as dependants of monasteries. They were capable of strong and violent action when provoked. Since their allegiance lay with a bishop or a monk, it is hardly surprising that they should have been mustered in force at times of stress. The vicious assault that led to the murder of the pagan Hypatia was, in all probability, the terrorist action to which the emperors alluded in their decree of the following year. Of the philoponoi even Zacharias, a friendly Christian writer, could say that they seemed terrifying to pagans.

The nexus of poverty and charity represented by these organizations greatly strengthened the power of the ecclesiastical authorities. This was a power that they did not hesitate to deploy, from time to time, in the form of urban terrorism. Such

27 Zacharias, PO 2, p. 24.

28 Loc. cit. (previous note).

29 E. WipsYZKa, "Les confréries dans la vie religieuse de l'Égypte chrétienne" Proceedings of 12th Int. Congress of Papyrology, Amer. Stud. in Pap. vol. 7 (Toronto, 1970), p. 511-525. 
violence, carried out by social workers in a Christian cause, had its roots in urban poverty. The healthy poor in a city could provide a formidable private army that threatened the balance of authority between church and state. The scraps of testimony we have been able to examine here suggest that both Theodosius and Justinian were keenly alert to this danger.

G.W. BOWERSOCK

Institute for Advanced Study

1 Einstein Drive

Princeton NJ 08540

gwb@ias.edu 